\title{
Sport Tourism: Understanding the Concept, Recognizing the Value
}

\author{
Ramesh Raj Kunwar*
}

\begin{abstract}
The study of sport tourism has become a very popular in the western countries. Therefore, it is aimed at grasping the knowledge of sport tourism from those studies: its nature, scope, significance, concepts, theories, approaches, models, perspectives and paradigms. This paper is intended to provide a broad understanding of sport tourism and its implications to the people who are involved in tourism industry. It is believed that activities of sport and tourism build social capital by bringing people together and establishing their relationship. In this way they are making the world smaller place contributing to greater understanding between different cultures, tolerance and, ultimately, to world peace with a focus on adventure sport tourism. The study of sport tourism is equally important in the context of Nepal because it is one of the popular destinations for adventure sport tourists and tourism. This paper discusses on water sport in terms of whitewater river rafting tourism in the context of Nepal, which is still ignored and untouched in the field of academia.
\end{abstract}

Keywords: sport tourism, sportification of society, typology of sport tourism, nostalgia, adventure sport tourism, water sport in Nepal.

\section{Research Methodology}

Tourism has been studied by several western scholars of different disciplines such as management, ecology, environment, political science, economics, geography, anthropology, sociology, gender, human resources management, law, crisis and disastrous management, conflict and peace studies, psychology, religion, heritage and conservation and others. In the context of Nepal, most of the tourism scholars confined their studies only in the field of mountain tourism and wildlife tourism but no studies have been carried out in the field of whitewater river rafting as one of the promising sectors of tourism in Nepal. Therefore, realizing the importance of sport tourism, adventure travel and water sport, the present author carried out research for understanding the concept and recognizing the value of sport tourism education.

\footnotetext{
${ }^{*}$ Prof. Dr. Ramesh Raj Kunwar is tourism educationist and anthropologist by profession. He is the former Dean of Faculty of Humanities and Social Sciences, Tribhuvan University, Kathmandu, Nepal, and former Dean of (then) Royal Nepalese Military Academy, Kharipati, Bhaktapur. Currently, he is teaching at the Central Department of Culture, T.U., Kathmandu, Nepal. Email: kunwardr@gmail.com.
} 
Writing in 1989, Jafari predicted that the 1990s would be dominated by a knowledge based platform in which the ideology-driven platforms of the past would be supplanted by a more scientific and objective basis for conceptualizing and managing the tourism sector... (Weaver, 2001, p. 4). Therefore, this study has been carried out under the concept of knowledge based platform. Both as an applied and social field of study, it is inevitable that academics should be involved in supplying research to the academia, industry and government. 'Understanding the Concept, Recognizing the Value' as an approach has been borrowed from Williams (2010) for making the title of this study.

Tourism research scholars follow global research methodology as followed by the other disciplinarians. According to Rosenau (1992), (research) "method concerns how one conducts research, analyses the data or evidence, test theories and creates new knowledge" (in Repko, 2012, p. 128). Methodologically this paper has been reviewed from published literatures related with sport tourism, adventure travel and aqua tourism in Nepal. Basically this work is based on interdisciplinary approach. According to Vinsentine (2011: xiii), "... interdisciplinary is a means to identify and study new themes that single discipline would not be able to put into focus, describe interpret by themselves". Newell (2007, p. 240) writes, "interdisciplinary study is a two part process: it draws critically on disciplinary perspectives, and it integrates into a more comprehensive understanding... of an existing complex, phenomenon [or into] the creation of new complex phenomenon" (in Repko, 2012, p. 15). Weaver and Lawton (2002) argue that the multi-disciplinary approach in tourism research is gradually evolving into an interdisciplinary approach, where the perspectives of various disciplines are combined and synthesized (Melkcort \& Vos, 2010, p. 37).

The research which has been completed without following proper research methodological tools and techniques is known as sloppy science (Ritchie et al., 2005, p. $2,5)$. Therefore, with careful consideration during the research, the author has followed the proper methodological approaches. In course of collecting the data, fieldwork was carried out by the author following mystery shopping during the rafting trips in the Trishuli river of Nepal. Fieldwork is a way of producing knowledge based on the researchers' experiences, i.e. a direct contact with reality, a knowledge by repeated observations and/or by proof of ideas or hypotheses (Hessen, 1961; in Pereiro, 2010, p. 175). Mystery shopping is a form of participant observation, which Loafland (1971: 93) describes as ' ... the circumstances of being in or around an on-going social setting for the purpose of making a qualitative analysis of that setting' (Miller et al., 2005, p. 119). Mystery guest method has also become another methodology, in which a participant is asked to evaluate experiences and identify important factors that influence the nature of experiences from a guest's viewpoint (Huckstein \& Duboff, 1999: in Xie, 2006, pp. 128-129). The unstructured interviews were also taken with the authorities of Nepal Association of Rafting Agents (NARA), some entrepreneurs and Women River guides. Thus, the field and respondents have become the sources of primary data. The information is also collected from secondary sources. Over all, the researcher followed qualitative research method in this study.

Qualitative research recognizes the human relations are complex and focuses on human experience. The justification for using qualitative tools and techniques as opposed to quantitative lies in the fact that it allows more information and perceptions to be obtained 
from the people involved and it provides an opportunity to allow them to directly describe and analyze situations. Qualitative research will achieve holistic view of the given issues and will take the wider picture in perspective. Interview is an essential tool in qualitative research method. The semi-structured interviews used in this research allow for a high level of researcher's involvement with participants. Likewise, open-ended questions allow for the participants to discuss and talk about subject matter that may not be included in questionnaire. It, therefore, allows honesty and brings out a greater reality of situation.

\section{Concept of sport tourism and its development}

Though, there are several definitions about sport, one of the most influential definitions of sport has been given by Loy et al. (1978). The authors conceptualize sport as a subset of games which in turn is a subset of play. Sport is described in terms of institutionalized games that require physical prowess. Their study on sport is based on game occurrence approach. Further, Young-Shim (2004) defined sport as a professional, amateur or leisure activity that involves "a considerable amount of traveling to play and compete in different destinations and countries" (p. 24). In a similar fashion, McPherson et al. (1989) defined sport as "a structured, goal oriented, competitive, contest based ludic physical activity" (p. 15).

Law (2001) stressed, "Sport is structured in the sense that sports are governed by rules that relate to space and time. These rules may be manifest in a variety of ways, including the dimensions of the playing area and pacing of the game or contest" (in Hinch and Higham, 2006, p.16). Hinch and Higham (2006) argued that "Sport is goal-oriented in the sense that sporting situations usually involve an objective for achievement in relation to ability, competence, effort, degree of difficulty, required skill set and mastery or performance. At one extreme, competition is expressed in terms of winning or losing. Alternatively, competition can be interpreted much less rigidly in terms of competing against individual standards, inanimate objects or the forces of nature (p. 16).

The terms "sport tourism" and "sports tourism" have been defined differently (Hinch \& Hingham, 2006). Gammon and Robinson (1999) pointed out " Sports Tourism focuses upon competitive sporting travel, whereas the term Sport Tourism is a far broader concept which embraces sport as being both recreational as well as competitive: both institutionalized and transitory (in Hinch and Higham, 2006, p. 13). The terms sport and sports are often used interchangeably in tourism studies; however, a lack of subject uniformity, cohesiveness and perhaps academic credibility create confusion among people including tourists, scholars, entrepreneurs and so on.

So far as the tourist and tourism is concerned, if a tourist is a person who involves in travelling, tourism involves the travel of non-residents (Murphy, 1985). Hinch and Higham (2001) define sport tourism as 'sport - based travel away from the home environment for a limited time, where sport is characterized by unique rule sets, competition related to physical prowess and a playful nature. According to the authors, sport is recognized as a significant travel activity whether it is primary or secondary feature of the trip.

The concept of sport tourism has become more prominent in the last few years as both 
an academic field of study and an increasingly popular tourism product (Gibson, 1989). By recognizing the importance of sport tourism, the academia, government and nongovernmental organizations have been involved in research around the area of sport tourism at the international and national levels. However, the links and relationship in between sport and tourism have largely been overlooked. More importantly, the genre of 'sport tourism' (of sport generating tourism activity or tourism generating sporting activity) is a recent research development (Ritchie \& Adair, 2006, p. 3).

The early studies into sport tourism in the UK first appeared the 1960s, but the most recognized works have been undertaken by Glyptis (1991) and Redmond (1991) who were concerned about identifying a complex, multi-faceted, symbiotic link between sport and tourism. The authors suggested the development of sport and tourism is crucial for social and economic benefits. Sports tourism is one of the most entertaining and exciting tourism.

Research Notes (1994) reported that sport tourism, a growing segment of tourism, has been shown to equal $32 \%$ of worldwide tourism receipts (in Kurtzman and Zauhar, 2006).World Tourism Organization (2001) has indicated that the contribution of sport and tourism to the gross domestic product (GDP) of industrial nations is between $1-2 \%$ and 4-6\% respectively (in Ritchie and Adair, 2006, p.2).

Young-Shim (2004) argued that tourism and sport are interrelated and complementary. The author further stated that " Both are powerful forces for development, stimulating investment in infrastructure projects such as airports, roads, stadiums, sporting complexes, hotels and restaurants-projects that be enjoyed by the local populations as well as visitors who come to use them. And once the infrastructure is in place, these two mutual beneficial industries of tourism and sport tourism become the motor for sustainable economic growth, the creation of employment and generation of revenues" (p. 25). The author argued that activities of sport and tourism build social capital by bringing people together and establishing their relationships. "In this way they are making the world a smaller place-contributing to greater understanding among cultures, greater tolerance and, ultimately, to world peace" (p. 25).

Sport is regarded as playing a positive role with respect to community development: 'the strengthening of the social resources and processes in a community, by developing those contacts relationships networks, agreements and activities outside the household that residents themselves identify will make their locality a better place in which to live and work (Thomas, 1995, p. 2; in Hall, 2006 p. 194). The study suggested that sportsrelated employment can contribute to 'neighborhood renewal' and community development (McDonald \&Tungatt, 1992; in Hall, 2006, p.194).

Young-Shim (2004) highlighted the common goals of sport and tourism:"building bridges of understanding between different cultures, lifestyles and traditions, promoting peace and goodwill among nations; motivating and inspiring young people and providing entertainment and enjoyment to relieve the pressures of daily life for large sections of the population" (p. 24). 


\section{Typology of Sport Tourism}

Gammom and Robinson (1997) have developed the following conceptualization of sport tourist based on the sport and travel motivations:

Sport Tourism - Individuals and/ or groups of people who actively or passively participate in competitive or recreational sport while traveling. Sport is the prime motivation to travel, although touristic element may reinforce the overall experience.

Hard Definition - Active or passive participation in a competitive sporting event. Sport is the prime motivational reason for travel (e.g. Olympic Games, Wimbledon, London Marathon).

Soft Definition - Active recreational participation in a sporting leisure interest (e.g. skiing walking, hiking kayaking).

Tourism Sport - Active or passive participation in competitive or recreational sport as a secondary activity. The holding or visit rather than the sport, is the prime travel motivation.

Hard Definition - Competitive or non-competitive sport as an important secondary motivation that enriches the travel experience (e.g. sports cruises, health and fitness clubs).

Soft Definition- Competitive or non-competitive sport or leisure as a purely incidental element of the holiday experience (e.g. mini golf, indoor bowls, iceskating, squash).

By following the concept of Standeven and De Knop (1999), Hinch and Higham (2006) illustrated the diversity of the sport tourism market:

\begin{tabular}{|l|l|}
\hline \multicolumn{1}{|c|}{ Classification } & \multicolumn{1}{c|}{ Examples } \\
\hline $\begin{array}{l}\text { Sport activity holidays: } \\
\text { Single-sport activity holidays } \\
\text { Multiple- sport holidays }\end{array}$ & $\begin{array}{l}\text { skiing, cycling, trekking } \\
\text { sports camps, holiday clubs (e.g. Club } \\
\text { Mediterranee) }\end{array}$ \\
\hline $\begin{array}{l}\text { Holiday Sport Activities: } \\
\text { Organized holiday sport activities } \\
\text { independent holiday sport activities }\end{array}$ & $\begin{array}{l}\text { golf, rafting, cruise ship sport activities } \\
\text { adventure activities (e.g. bungee jumping) }\end{array}$ \\
\hline $\begin{array}{l}\text { Passive sports on holidays: } \\
\text { Connoisseur observer } \\
\text { Casual observers }\end{array}$ & $\begin{array}{l}\text { Olympic Games, Masters golf, Wimbledon } \\
\text { tennis championship, Kentucky Derby, } \\
\text { museums, halls of fame, stadium tours hurling } \\
\text { (Ireland) Bull fighting (Spain), Thai boxing } \\
\text { (Thailand) }\end{array}$ \\
\hline Active sports during non-holiday time & $\begin{array}{l}\text { training camps, recreational sport during } \\
\text { business and conference travel }\end{array}$ \\
\hline Passive sports during non- holiday time & $\begin{array}{l}\text { dragon boat racing spectatorship while in Hong } \\
\text { Kong on business }\end{array}$ \\
\hline
\end{tabular}


As mentioned earlier, Standeven and De Knop (1999) have identified two types of passive spectators that watch sport events termed 'connoisseur' and 'casual' observers (in Ritchie and Adair, 2006). Connoisseur observers are 'those who have extensive passive involvement and discriminating in the sport activity they watch as spectators or officiators'. Casual observers are those who 'simply enjoy watching an event and who usually happen across it rather than plan their visit to attend it'. Taking into consideration Gammon and Robinson's (1997) 'soft' and 'hard' definitions and sport tourist motivations toward the sport or travel potential passive spectators may be dominated by travel and tourism or by sport.

Glyptis $(1989,1991)$ introduced the terms 'general dabbler' and 'specialist' to describe different levels of tourist engagement in participant and spectator sports. Hall (1992b) also identified two types of sport tourists; 'activity participants' who regard their participation as a medium of self-expression, and 'players' who are competitive in their participation. The World Tourism Organization and International Olympic Committee (2001) conducted the study and found the distinction between 'sport- oriented holidays' and 'less sport oriented holidays' is the conceptual basis for the study of sports activities during the outbound holidays of German, Dutch and French (in Hinch \& Higham, 2006, p.34). Those are distinguished on the basis of spectatorship and physical participation, which is a fundamental difference that merits consideration.

From one survey it is evident that the sport tourist spectator is motivated primarily by the sport known as 'avid spectator'/fan, motivated primarily by the travel known as 'casual spectator' and with a potential mixed interest group known as 'frequent spectator'. The 'avid spectators' are connoisseur observer and 'hard' tourists. Watching competitive sport is their prime motivation. Frequent spectators regularly watch Super 12 matches, however they do not have the same enthusiasm for the sport as 'avid' spectators. Casual spectators will have lower interest levels towards the sport. They are soft sport tourist motivated more toward tourism or other motives with sport being secondary (Ritchie, 2006, p.144 -145).

Sport-as-play normally associated with active tourist behavior (taking part in sport), while sport-as-competition is usually associated with passive tourist behavior (witnessing sport) -though in the latter case sports tourists can also be competitors, such as with young tennis players, following the satellite circuit in Europe, playing to win but sightseeing between matches. "Both sport - as - competition and sport-as-play are legitimate ways of conceptualizing the physical activities we take for granted as sport" (Ritchie \& Adair, 2006, p. 5). Coakley (2001) argued that there should be at least three persons (two taking part and a third to act as referee or judge), and they must be engaged in competition to establish a winner (in Ritchie \& Adair, 2006, p. 5).

Standeven and De Knop (1999) define sport tourism as all forms of active and passive involvement in sporting activity, participated in casually or in an organized way for non-commercial or business/ commercial reasons that necessitate travel away from home and work locality. Gammon and Robinson (1997) classify them as either 'hard' or 'soft' participants. Kurtzman (2000) increases the complexity of sport tourism by suggesting that there are five main sport tourism categories (or supply side elements of sport tourism). 
The categories are: (a) sport tourism attractions; (b) sport tourism resorts; (c) sport tourism cruises; (d) sport tourism tours; (e) sport events tourism; and (f) sport adventure tourism. However, Gibson (1998) suggests three categories of sport tourism including active sport tourism, event sport tourism, and nostalgia sport tourism. Three key questions emerge in the context of sports tourism development: (a) 'What makes sport unique as a tourist attraction or activity?; (b) 'How is sport tourism manifest in space?' and (c) 'How do these manifestations change over time?' (in Ritchie and Adair, 2006: 8) .

Additionally, Pitts (1999) believed that from a sport marketing and management perspective, sport tourism consists of two broad product categories (p.31). They are: sport participation travel and another spectatorial travel. Sport participation travel involves recreation, leisure or fitness activity, and sport spectatorial involves travel of watching sports, recreation, leisure or fitness activities and events.

\section{Sport tourism development}

While writing about the modern development of sport tourism, Hinch and Higham (2006, p. 5) have collected the cross-section of contemporary trends presented by various scholars that include:

1) The expanding demographic profile of participants in sports (Glptis, 1989);

2) Heightened interests in health and fitness in western societies since the $1970 \mathrm{~s}$ (Colllins, 1991);

3) Increasing demand for active engagement in recreational pursuits while on holiday since the 1980s (Priestley, 1995); and

4) Growing interest in the prominent roles played by sports and sports events in urban renewal and urban imagery, and the potential to leverage tourism opportunities associated with sports events (Getz, 1998).

What are the foundations for sport tourism development? This will talk about the fundamentals in the study of sport tourism, sport tourism markets and development processes and issues relating to sport tourism. It is equally important to know about sport tourism development in relation to space, place and environment. The next important areas of sport tourism development is its relation to time i.e. short-term, medium-term and long-term time horizon which provides a temperate framework that allows the readers to consider the immediate sport tourism experience, sport tourism seasonality, and its dynamic interrelationship between sport and tourism within evolutionary framework.

Weed and Bull (1999) contended that there are five key factors- ideology, government policy, organizational structure, organizational culture, and key staff- that impact upon the relationship between sport and tourism agencies (in Deane and Callanan, 2006). The specific influence of each of these factors is 'responsible for the limited and fragmented patterns of liaison that have emerged. These processes have been driven by economic and political forces, and by changing social attitudes and values. They have also been facilitated by technological advances, such as satellite television broadcasting (Halberstam, 
1999), that have influenced the 'sportification of society' (Standeven and De Knop 1999; in Hinch and Higham, 2006, p.5).

\section{Sport Tourism Motivations}

'Who are sport tourists?" What factors motivate sport tourists? To what extent do motivations differ between distinct groups of sport tourists? 'And what travel experiences do sport tourists seek in association with the sport that they pursue at a given destination?' Addressing these questions will provide valuable insights into niche market segmentation decisions. Market analysis, then, is critical to the effective development of sport tourism within the context of regional, national or international tourism destinations (Hinch \& Higham, 2006, p. 33).

The diversity of sport tourism market is a motivating factor. Therefore, the varied approaches to market segmentation that exist in sport tourism. The concept of 'workplay, freedom-constraint, competition recreation, and process product are only some of the continua on which sport can be located. The motivations associated with sport tourism niche markets raise intriguing questions for sports events organizers and promoters sport associations, managers of sport venues, destination managers, and tourism marketers.

The logical extension of this market analysis is consideration of development processes, sustainability and planning interventions. Development issues that are of particular interest to sport and tourism practitioners include those related to commodification/authenticity, globalization and industry fragmentation. Sport tourism development and space is interrelationships linking sport tourism generating areas and destinations with the travel patterns associated with sport tourism markets. The basic concepts and themes are roots in economic geography. These concepts are drawn from the study of sport geography and the spatial analysis of sports.

Tourism development processes, as conceptualize in the evaluation in tourism destinations through a life-cycle (Butler, 1978) may be influenced by the powerful dynamics of sports for example, evolving spatial patterns of sports may have a direct bearing on tourism development. The reverse is also true; tourism may impact upon the types of sports practiced in destination areas. Golf serves as a good illustration of this process, given its introduction into the 'new world' by Scottish migrants and diffusion into new regions throughout the world in response to tourist demand.

Redmond's tripartite sport tourism classification includes sport vocations, multi-sport festivals and world championships, as well as sports halls of fame and museums (Hinch \& Higham, 2006, p.39). Sport tourism, according to Gibson (1998), can be divided into three categories: active sport, event sport and nostalgia. Active sport tourism consist of several activities including: skiing, bicycle touring, adventure tourism and active participation events or other sporting tournaments. The most widely researched examples of event sport tourism include the Olympic Games, the Soccer World Cup, the Rugby World Cup, the Formula One Grand Prix and major or local sporting events (Ritchie \& Adair, 2006, p. 136).

In basic terms, nostalgia can be described as a longing for the past; or, more precisely a past that is simpler and thus preferable to a complex present. Nostalgia is a feeling of 
loss or anxiety about the passage of time, accompanied by a desire to experience again some aspects of the past (Jafari, 2000, p. 415). Rooney (1992) commented that nostalgia sport tourism is a unique form of tourism in which tourists search for sporting sports experiences associated with earlier periods. Nostalgic sport tourism presents the opportunity to revisit periods where sport was attached more strongly to place. It provides sport tourists with the opportunity to connect to place in a way that seems to be increasingly difficult in the modern world. Nostalgia sport tourism has been actively developed in North America (in Hinch \& Higham, 2006, pp.79- 89). The situation of locational flux has in many cases taken place in association with development of the tourism product, including tourist attractions that target the nostalgia sport tourists. In sports studies, for example, scholars have been interested in the use of sporting nostalgia to augment conservative political campaigns. There are various types of nostalgia, e.g. active nostalgia, restorative nostalgia, social nostalgia, environmental nostalgia, historical nostalgia, personal nostalgia and sporting nostalgia (Jafri, 2000; Ritchie \& Adair, 2006; Tarlow, 2009).

\section{Sport tourism and culture}

Sport and culture are often treated as separate but complementary activities. The treatment is particularly evident at major sporting events, which may have distinct culture and sporting programs. Popular culture as manifested in sport is one of the main ways that humans develop personal and collective identities. It is through these personal and collective identities that place identity is developed. At its most basic, identity is the way that we perceive ourselves, as individuals and collectives, based on prevailing social and ideological values and practices (McConnell and Edwards, 2000; in Hinch and Higham, 2006, pp. 103-104).Identity is the way in which people make sense of the self through affiliation and bonds with other people and the cultures that define these affiliations (Dauncey \& Hare, 2000; in Hinch \& Higham, 2006, p.104). National identity is typically thought of in the way that nations differ from each other in terms of stereotypes, symbols and practices, including those associated with sport. Place identity is influenced by many cultural attributes, but sport certainly appears to be one of the most dominant.

Regarding place, sport and culture, Standeven and De Knop (1999) write, "We have essentially treated sport and tourism as cultural experiences sport as a cultural experience of physical activity and tourism cultural experience of place". Place is intimately tied to culture (p.58). Culture relates to sport in a number of ways, but three of the most tangible associations are: (1) cultural programs run in association with sport events; (2) sport as a form of popular culture; and (3) subcultures in sport. Each of these cultural dimensions influences the meaning that is attached to sport spaces, and in so doing, they affect place identity, and potentiality, place marketing for tourism (pp.102-103).

The opening and closing ceremonies of the Olympic Games provide a good example of the conscious mix of sport and culture. There are three types of narrative approaches associated with the opening ceremonies of major sporting events. Moragas Spa (1995) have categorized them as history, party and show (in Hinch \& Higham, 2006, p.105). In the first case, the ceremony is treated as a 'unique historic event taking place in that 
moment, although forming part of a historic chain'. In the second stance, the ceremony is treated as a celebration and pays particular attention to the event's cultural aspects. 'It is a peak experience; an explosion of culture, theatre and joy. Finally, the third type of ceremony is one of the entertainments. This type of ceremony down plays the 'distraction' of the cultural and ritual structures of the desert and tries to provide 'an entertaining introduction to the "real" excitement. Each of these three approaches, but most particularly the second, may serve the explicit positioning of culture in relation to place.

"... The Athens 2004 Olympic Torch Relay traveled the globe proclaiming 'pass the flame, unite the world'. The Olympic flame is the primary symbol of the Olympic ideals; noble competition, friendship and peaceful coexistence. Apart from sports, education and tourism are the only other ideals that promote similar principles and can contribute to a more peaceful, prosperous and equitable world. Tourism is also increasingly responsible for poverty alleviation and for a greater understanding of our world-leading to peace" (Buhalis \& Costa, 2006: Preface).

Pierre de Coubertin's, 'the founding father' of the modern Olympic Movement and the author of the Olympic ideals and principles, definition of Olympism involved four key principles that suggest he had in mind something more advanced than a simple sports competition (OLM, 2002; in Ritchie and Adair, 2006, p. 59): (a) Olympism is a religion. Its followers are expected to adhere to an ideal of a 'higher life' and to strive for human perfection; (b) The Olympic Games represents and displays an elite group "whose origins are completely egalitarian' and its character both moral and chivalrous; (c) The Olympic Games is 'a four-yearly festival of the springtime of mankind' during which a truce to conflicts is created; and (d) Olympism glorifies beauty by the 'involvement of the philosophic arts' in the games.

\section{Sport Tourism, Locations and Seasonality}

The tourism industry is in the business of selling places. Space and place are concepts that are central to the geography of sport and the geography of tourism (Bale, 1889; in Hinch and Higham, 2006). The spatial analysis of sport tourism involves the study of the location in whish sports occur and the movement of tourists to these locations. Such an analysis finds theoretical foundation in the geography of sport (Bale, 1989), which introduces central place theory, distance decay and location hierarchy for consideration in the study of sport tourism. Central place theory is a particularly useful tool to explain the locational tendencies of urban sport facilities, events and professional sport teams. Bale (1989) refers to 'the growth and decline in importance of different sport location', which parallels Butler`s (1980) tourist area life cycle theory (p.77).

The next important aspect of sport tourism is place which may be described as space with meaning. It is especially attractive to tourism marketers who use sport to sell destinations (Hinch \& Higham, 2006, p. 119). Both place and space are also related with landscape. The landscape is an illusive term that is commonly associated with attractive scenery (see in detail Knudsen et al., 2008, pp. 1-21). Natural landscapes (and seascapes) are central to the pursuit of many sports. The term sportscape is used in the geography of sport to describe the highly modified (e.g. modern stadium or arena) and technologized 
(e.g. corporate suites, closed circuit television) sports environment (Bale, 1994; in Hinch \& Higham, 2006, p.119).

It is evident that the most of the sport tourism places as destinations are commodified through the process of marketing. The primary goal of a place marketer is to construct a new image of the place to replace either vague or negative images previously held by residents, investors and visitors (Page and Hall, 2003; in Hinch \& Higham, 2006, p.109) . In his seminal work, Place and Placelessness, Relph (1976) argued that the concept of sense of place was most applicable in the local environment, where individuals are in a position to develop deep attachments to place (in Hinch \& Higham, 2006, p.100). The study of the locations and travel flows associated with sports, the way sport infuses space with meaning to create unique tourism places and the resource requirements and impacts of sport tourism are all key themes within the spatial analysis of sport tourism development (Hinch \& Higham, 2006, p. 208).

Seasonality is the mid-point on the sport tourism development temporal framework. "Seasonality is defined as a temporal imbalance in the phenomenon of tourism, which may be expressed in terms of dimensions of such elements as numbers of visitors, expenditure of visitors, traffic on highways and other forms of transportation, employment and admissions to attractions" (Butler, 2001; in Hinch \& Higham, 2006, p.163).

\section{Sport Tourism, Research and Education}

Ritchie \& Adair (2006, pp.15-16) while writing about the significance of sport tourism, research and education, they suggest to follow multi or interdisciplinary research to have more insights between the relationship of sport and tourism, its impacts on the economy, society and tourists, and managing many of the issues surrounding the development of sport tourism. Research in the field of sport tourism should endeavor to involve where appropriate, researchers from different disciplines and departments within universities (such as leisure, recreation, tourism, history, anthropology, management). Academics in leisure, recreation, tourism, sport, management and social scientists could work closure together to provide subjects and materials to facilitate the development of specific sport tourism modules, sport tourism specialization and even sport tourism degree programs at undergraduate and postgraduate levels. Swart (2000), in research undertaken about sport tourism curricula, noted that from the 28 academics surveyed, 84 tourism courses were offered, $78 \%$ of respondents confirmed that sport tourism was taught in existing cause models. The growth of collaboration and interdisciplinary research in the sport tourism area will heighten the awareness and legitimacy of sport tourism as a field of study and provide additional insights to researchers. This will help to understand the concept and recognize the values of sport tourism as a phenomenon for research, policy, industry and education development or pedagogical development in sport tourism.

\section{Sport Tourism and Crime}

There is increasing evidence that sporting events attract criminals who engage in illegal activities. This requires an understanding of the nature of sport tourism and the potential for increased criminal activity within the host destination, whether directly or 
indirectly attributable to an event. The crimes may be highly organized activities by groups of criminals who travel to different destinations to prey on visitors attending major global sporting events. The event experience may involve overnight stays in accommodation and additional social activities, both of which have implications on criminal and hedonistic activity.

In some cases, travel to these events is part of the sporting experience and where the influence of crime may arise as nuisance outliers; negative impacts occurring some distance from the sporting venue, associated with the spatial impact of sport (e.g. at transit points such as bars, service stations, and convenience stores) (Bale, 1989). Public drunkenness, disorderly behavior and vandalism by event visitors are common nuisances and these have widespread impacts on the local community (Ritchie \& Adair, 2006, pp. 176-177).

The massacre of members of the Israeli team by Palestinian terrorists at the 1972 Olympics provided an explicit example that terrorist activity can be confined to specific targets at an event. In fact, the major development in security at the Olympic Games only arose as a significant planning issue in response to the terrorist attack at the Munich Games (Barker, 2000; Thompson, 1999).

Such negative effects raise the potential host/guest conflict. Jones (2000) applies the concept of serious leisure to football fandom in an attempt to explain the behaviors of football fans as part of the social identity process (in Hinch \& Higham, 2006, p.157). The characteristics of serious leisure in this context include longevity in support of a chosen team, strong identification with the chosen leisure activity, investment of significant personal effort and existence, in some cases, of a career path involving stages of achievement and recognition. 'Sports junkies' are tourists whose behaviors are indicative of a strong commitment to their sport or support for their team. The behavior of these sport tourist may create aversion effects (Faulkner et al., 1998), while contributing to accommodation shortages that displace other forms of tourism, such as corporate, business and conference travel (Hinch \& Higham, 2006, p.157).

Hooliganism has become a problem in the field of football events throughout Europe. Modeling is an important aspect of this form of social identity construction, whereby 'the neophyte member begins to deliberately adopt mannerisms, attitudes, and styles of dress, speech and behavior that he or she perceives to be characteristic of the established members of the subculture' (Donnelly \& Young, 1988; in Hinch \& Higham, 2006, p.157). It is logical, therefore, that planners of events intend to maximize positive returns and minimize any negative impacts (such as crime) associated with them.

In an event environment, disorderly and hedonistic behavior involving alcohol and drugs may increase, as many crime and recreational disorder. This can lead to the 'demonstration effect', where, for example, youths are exposed to illegal influences like drugs from event visitors, while seasonal employees emulate the hedonistic lifestyle sometimes associated with public events (Hall et al. 1995; in Barker, 2006, pp.178-179). According to Graham M. S. Dann (in Jafari, 2000, p. 275), "Hedonism is the unbridled pursuit of pleasure. Instant gratification of the ego and its anticipation are characteristics of the tourist as child. Experientially, hedonism can be particularly ego enhancing in 
Third World settings visited by First World tourists, which may explain why some allinclusive resorts are so designated. Motivationally, hedonism is linked to the behavioral excess exhibited in activities sanctions at home".

\section{Residents` Perceptions on Sport Tourism}

Sport tourism researchers are also concerned with the impact of tourism on local community. They have studied on community`s reactions towards the sport tourism events and have found both positive and negative reactions. It is Fredline who studied on Motor Sport Events in Gold Coast and Adelaid Grand Prix of Melbourne, Australia. Various authors have suggested possible theoretical frameworks for understanding the reactions given by the different communities of different tourist destinations. The theories are Social Exchange Theory and Social Representation Theory (see in detail Kunwar, 2012) and Expectancy -Value (EV) Model.

Ap has suggested that social exchange theory developed by Emerson in 1972 is helpful in understanding residents ' perceptions of the impacts of tourism and that exchange behavior is related to perceptions (Ap, 1992; Fredline, 2006, p. 165; see in detail Kunwar, 2012). It is suggested that residents will have more positive perceptions of tourism if they perceive that their tourism exchanges bring them substantial benefits, but will have negative perceptions of tourism if they perceive these benefits to be outweighed by substantial costs.

Alternatively, Pearce et al. (1996) have proposed the use of social representation theory (in Fredline, 2006). This theory suggests that residents have representation of tourism and events which underpin their perception of impacts, and these representations are informed by direct experiences, social interaction and other sources of information such as the media. It is argued that representations are resistant to change because they form a frame of reference through which new information is interpreted (p. 165).

The tenets of these theories are not contradictory. However, a substantial difference lies in the confidence they place in the rationality of the human mind. The social exchange approach tends to suggest the residents can rationally weigh up the costs and benefits of tourism or events, and their overall disposition toward the phenomenon will reflect some sort of informal cost benefit analysis. In contrast, social representation theory suggests more of an instinctual reaction based on a range of underlying values and attitudes. The theory also acknowledges the tenacity of these values and attitudes which underpin representations and the fact that they are socially reinforced, thus social representations are seen as being fairly persistent (Fredline, 2006, p.165).

Another potential theoretical framework is the expectancy-value model as mentioned above. This theory has been tested by Lindberg and Johnson(1997) in a general tourism context, found that the interaction between the importance that residents place on certain outcomes(value) and the degree to which they believe tourism to contribute these outcomes(expectancy) has some utility in explaining variation in attitudes towards tourism (Fredline, 2006, p.166). 


\section{Adventure Sport Tourism}

As mentioned earlier, adventure tourism is one of the most important parts of sport tourism. Therefore, an effort has been made to understand its scope, because the following sections are based on the study of whitewater rafting as an adventure sport in Nepal.

The Oxford Dictionary defines adventure as 'unexpected or exciting experience; daring enterprise, hazardous activities'. Its Australian equivalent, The Mauarie Dictionary, gives several meanings, including 'an exciting experience' and 'an undertaking of uncertain outcome; a hazardous enterprise. The US equivalent, Webster, gives a series of definitions, including 'a remarkable experience', the encountering of risks; hazardous enterprise', and 'a bold undertaking, in which hazards are to be met and the issue hangs upon unforeseen events; a daring feat'. All these definitions thus include elements of excitement, of uncertainty, and of risk and danger (Buckley, 2010, p.8).

Swarbrook et al. (2006, p. 15) write, "Although specific activities don't define adventure, it is apparent that adventure entails action. Adventure is not a passive experience; it's engaging. This engagement can be on physical, intellectual, emotional or spiritual level". Adventure travel is 'a leisure activity that takes place in an unusual, exotic, remote or wilderness destination. It tends to be associated with high levels of activity by the participant, most of it outdoors. Adventure travelers expect to experience various levels of risk, excitement and tranquility, and be personally tested .In particular they are explorers of unspoilt, exotic parts of the planet and also seek personal challenges (Millington et al., 2001 in Swarbrooke et al., 2003, p.28).

The question is when, where and how adventure tourism was originated and developed? The history shows that the adventure sport tourism was started from European Alps since 1741. When the two Englishmen Whindham and Pococke visited Chamonix in France, this marked the beginning adventure tourism. The decades that followed this first incursion into Alps saw the creation of hiking and mountaineering with the landmark event of the first scaling of Mont Blanc (4807 m) in 1786 (Holloway, 1994). This was followed by the first ascent of the Matterhorn by Edward Whymper's party in 1865. This successful and tragic trip led to the popularity and notoriety of that peak, as a result of an accident during their descent from the summit. Clients Douglas Hadow, Charles Hudson and Lord Francis Douglas, as well as guide named Michael Croz, fell to their deaths during the descent (Buckley, 2006, p. 261). A century and a half later the mountaineers introduced skiing into the Alps an activity which originated in Scandinavia and adapted it to winter climbs (1878-1924),...(Bourdeau et al.,2006, p.102).

The question is when, where and how adventure tourism was originated and developed? The history shows that the adventure sport tourism was started from European Alps since 1741. When the two Englishmen Whindham and Pococke visited Chamonix in France, this marked the beginning of adventure tourism. The decades that followed this first incursion into Alps saw the creation of hiking and mountaineering with the landmark event of the first scaling of Mont Blanc (4807 m) in 1786 (Holloway, 1994). This was followed by the first ascent of the Matterhorn by Edward Whymper's party in 1865 . This successful and tragic trip led to the popularity and notoriety of that peak, as a result of an accident during their descent from the summit. Clients Douglas Hadow, Charles 
Hudson and Lord Francis Douglas, as well as guide named Michael Croz, fell to their deaths during the descent (Buckley, 2006, p. 261). A century and a half later the mountaineers introduced skiing into the Alps an activity which originated in Scandinavia and adapted it to winter climbs (1878-1924),...(Bourdeau et al.,2006, p.102).

Adventure tourism is a worldwide industry with a total annual turnover of around US\$ 1 trillion (Buckley, 2009a). In the USA alone, the scale of the outdoor tourism sector has been estimated at US\$ 730 billion per annum (Outdoor Industry Association, 2007). At a global scale, it appears that the outdoor and adventure subsectors make up about one-fifth of the global tourism and travel sector (Buckley, 2009a), which in turn comprises about $11 \%$ of the global economy (WTTC, 2007; in Buckley, 2010).

Adventure tourists can be divided into those participating in hard or soft adventure, in which Millington (2001; in Swarbrooke et al., 2003, pp. 104-105) has defined as follows:

Hard adventure travel requires an element of experience in the activity being undertaken, and because it encompasses and element of risk, participants must be physically and mentally fit. It includes an intimate experience with the environment and culture of the destination. Participants should be prepared for all weather conditions, sleeping arrangements and dietary restrictions. Examples include: climbing expeditions, arduous treks, hang gliding, rock climbing, white-water kayaking and wilderness survival.

Soft adventure requires less physical risk, little or no experience, and offers more convenience in terms of sleeping arrangements and cuisine. Many activities are similar to those in the hard adventure category, yet they occur at a less physically demanding level. Soft adventure offers a wider range of activities and adventure experiences for the traveler. Examples include horseback riding, rafting, sea kayaking, snorkeling, bicycle touring, camping, canoeing, cross-country skiing, dog sledding, surfing, walking tours, wildlife watching and windsurfing.

The scope of adventure tourism has commonly been expressed through lists of specific outdoor activities involved. Buckley (2006a) listed 35-40 such activities, some of them in aggregated categories. In alphabetical order, these were : abseiling, aerobatic aircraft flights, ballooning, black water rafting, bungee jumping, caving, cross-country skiing, diving, downhill skiing and snowboarding, expedition cruises, gliding, hang gliding, heliskiing and heliboarding, hiking, horse riding ,ice climbing, jet boating, kite boarding, mountain biking, mountaineering, off-road 4WD driving, Parapenting and paragliding, quad biking and ATV driving, rock climbing, sail boarding, sailing, sea kayaking, skydiving and parachuting, snowshoeing, surfing, whale watching, whitewater canoeing and kayaking, whitewater rafting, wildlife watching and zorbing (Buckley, 2010, p.5).

There are many adventure activities where guides need particular qualification in order to be able to lead commercial clients. The aim of the tour operator is to make the clients feel that they can safely and successfully engage in a high-risk activity, so as to increase the excitement and consequent satisfaction which the clients experience; but at the same time, to manage the activity as closely and carefully as possible so that actual risk to clients, guides, and the company is as low as possible (Morgan, 2006; in Buckley, 2010 , p. 55). The whitewater rafting industry apparently developed after the Second World War, using army-surplus pontoons to make rafts (Buckley, 2010, p. 217). 


\section{Tourism in Nepal}

The natural beauties of a destination along with sound environment attract people for making their holiday experiences. Nepal has full of natural beauties, diversity in culture and adventurous places. Tourism for Nepalese people is not an interest but it is compulsion because Nepal cannot compete with other developed countries from the viewpoint of development perspectives and so on. Tourism is a panacea for the development of Nepal. Tourism is an economic engineering. This will play important role of collecting foreign currencies and simultaneously it will provide employment opportunities to the people of host country.

Different authors have emphasized that sustainable tourism can be a promising vehicle for economic development and poverty reduction, unlocking opportunities for local economic diversification in poor and marginalized rural areas that lack other significant development opportunities (UNWTO, 2002; in Kruk, 2011, p. 19).

To reduce poverty, the United Nations Summit on the Millennium Goals adopted a global action plan to cut poverty levels in half by 2015 (United Nations, 2009). Povertyfocused tourism, such as pro-poor tourism, can be a key player in achieving the Millennium Development Goals by providing an alternative form of income in areas suffering from poverty, hunger, and disease-either directly or indirectly (UNWTO, 2010; in Nyaupane \& Poudel, 2011, p. 1346).

Pro-poor tourism is defined as using tourism in a way that creates net benefits to the poor (Harrison, 2008). Its definition implies that the poor benefits from the income provided by tourists, which can lead to more development in the area. The poor can be employed in tourism businesses, establish or run tourism enterprises, or receive donations or support from tourists. Tourism also provides a market to sell goods and services to tourists (Scheyvens 2007; in Nyaupane and Poudel, 2011, p.1346).

Tourists undertaking activities in Nepal can be divided into four major segments: Aerial, Terrestrial, Aquatic and Niches. The Aerial activities include mountain flight, hang gliding, paragliding, cable car, bungee jumping, ultra light air craft, hot air ballooning and sky diving. The Terrestrial includes mountaineering, trekking/hiking, jungle safari, wild life, honey hunting, mountain biking, rock climbing, caving, skiing, golf, elephant polo, motor rally, Himalayan marathon, triathlon, pony treks. The Aquatic includes rafting, kayaking, canoeing, boating, fishing, angling, canyoning, cascading, jet ski. The Niches include eco-tourism, village tourism, community tourism, agro-tourism, culture tourism, pilgrimage and spiritual tourism, educational tourism, health and wellness tourism, special interest tours (Govt. of Nepal, Ministry of Tourism and Civil Aviation, 2009, p. 13).

According to Nepal Tourism Statistics 2012, the total number of tourists visited Nepal was 803,092 in 2012 ( MoCTCA, 2013, p.2). Out of the total number of visitors, 379,627 visited for holiday/pleasure, 109,854 for pilgrimage, 105,015 for trekking and mountaineering, 30,460 for official, 24,785 for business, 17,988 for study/research/employment, 32,076 for conference/convention, and others 70,391. The maximum number of tourists visited from India, P.R. of China, Sri Lanka, USA and UK respectively by Indian Airlines, Jet Airways, Qatar Airlines, Spice Jet and Thai Airlines. The average length of stay of the tourists is 12.60 days. In an average, a tourist spent per 
day per person US Dollar 35.6. The government of Nepal collected 356,725 (US \$ `000) as revenue from tourism. There are 522 hotels with 11,087 rooms and 21,498 beds. The government registered Travel Agencies and Trekking Agencies are altogether 2,116 and 1,524 respectively. National Parks and Wildlife Reserves were visited by 267,280 tourists; Pashupati area (excluding Indians) - 139,885; Lumbini (excluding Indians) - 136,067; Manaslu trekking - 3,319; Mustang - 2,965; Humla - 1,508; Lower Dolpo - 982; Kangchenjunga - 635 and Upper Dolpo by 536 tourists. The total number of tourist guides and trekking guides are 2,935 and 8,163 respectively. The total team of mountaineering expeditions were 311 and the government of Nepal collected total NPRs 344,784 (Rs`000) as Royalty (MoCTCA, 2013, pp .2-3)

Realizing the importance of adventure tourism in Nepal, Dhakal (2013) suggests, "Probable new tourism products with blend of adventure sports could be golf played in exotic landscape in hilly locations; international cricket matches; optimum utilization and promotion of overlooked/undeveloped world class rapids in Nepali rivers to promote rafting; further promotion of elephant polo and elephant race as unique gifts to the world of adventure sports; marketing of Nepal as the world's fifth best paragliding location; and Nepal standing as the world's fourth country operating the bungee- jump and 'ultimate swing' professionally" (p. 66).

\section{River Rafting in Nepal}

Nepal has a reputation for being one of the best places in the world for rafting and kayaking with outstanding river journeys ranging from steep adrenaline- charged mountain streams to classic big volume wilderness expeditions (Lonely Planet, 2008; in Jarga, 2003, p.46). Likewise, Knowles (1994) also mentions that "Nepal is a river runners" paradise- no other country has such a choice of multi-day trips, away from roads, in such magnificent mountain surroundings, with warm rivers, a semi- tropical climate, impressive geography, exotic cultures, wildlife and friendly welcoming people!" (p.7). This industry has also provided employment, generated foreign currency and provided economic benefit to the riverine population of 'put-in' and 'take-out' points of the riverside. The activities are undertaken in different degrees of rough water to get thrill and excitement. The development of this activity as a leisure sport has been started since 1970s. Basically, the international tourists those who do rafting in Nepal, they can be divided into three groups: a) those who will visit Nepal specially for the purpose of rafting; b) those who will do rafting on the way back from trekking; and c) those who will go to Pokhara and from their they will join in rafting tour.

Nepal is a country of turbulent rivers descending feature and faster than anywhere else in the world. As a result, many rivers have cut steep valley thousands of meters deep, creating enormous, unstable hillsides. Around 6000 rivers are flowing in the country. The major rivers are Mahakali, Karnali, Kali Gandaki, Marshyangdi, Seti, Budhi Gandaki, Trishuli, Bhotekoshi, Sunkoshi, Balephi, Tamakoshi, Dhudkoshi, Arun and Tamur. ith They are the ever flowing source of beauty, inspiration, abundance and infinite adventure. The rugged topography, extreme variations and excessive snow melting, heavy monsoon rainfall make this country an obvious choice for river adventure. The raging rivers passing 
through mountain gorge exotic valley and jungles provide ample opportunities for thrilling and adventure activities. The term adventure water sport is interchangeably used with aqua tourism or whitewater river rafting or kayaking.

"Rafting means the travelling of tourists in rivers by using boat or raft like floating equipment for the purpose of entertainment or natural or cultural sightseeing"(HMG, MOTCA,1994, p. 49).Literally, whitewater is the white frothy stuff that splashes and tumbles through a rapid. In more general terms, it is used to describe a type of river where you can expect to find rapids (Mark, 2001, p. 247). A rapid is formed where the riverbed gets more steep, which are any collection of waves, holes, rocks and other features that paddles must negotiate (Mark, 2001, p. 245). Raft or river journeys last anything from a few hours to several days. This category includes a wide range of activity types, from exhilarating white water rafting to easygoing cruising river exploration (Swarbrooke et al., 2003, p. 34).

It is Nima Lama who has written the history of river rafting in Nepal in the book of Peter Knowles published in 1994. According to Lama (1994), "The first crazy river runners arrived in Nepal in the late 1960s". In this regard, Ranabhat and Thapa (2013) write, " The written record proves that it is only Sir Edmund Hillary and his friends made the first historical river journey at Sun Koshi river in 1968" (p. 77). This became the benchmark in the history of river rafting in Nepal, although it was not commercial tour. Historically, commercial river rafting activities started in Nepal only in 1975 (Ranabhat \& Thapa, 2013).

An experienced American river guide, Mike Yager came to Nepal in 1974 through Mountain Travel Company and made river journey in Trishuli. Subsequently, he was appointed as operation manager for organizing commercial rafting trip through Himalayan River Exploration under Mountain Travel- Tiger Tops since 1975. Himalayan River Exploration (HRE) was the first business rafting company which organized whitewater rafting trip in the rivers of Nepal.

For the purpose of implementing the rafting business, HRE advertised in the Rising Nepal for "Whitewater Rafting Guide Trainees". It finally selected eight men and they got an extensive training in Nepal and USA (Knowles, 1994, p. 65).

At the same time, the commercial rafting was developing, "expeditions "from overseas were arriving:

In 1975 Major Bashford Snell led an expedition out from Britain to conquer the Trishuli but had the misfortune to break his nose in one of the rapids - now named "Snell's Nose' in his honor. A Czech team of Kayakers attempted parts of the Dudh Koshi in 1973 and in 1976 a British team led by Dr Mike Jones made an award winning film that would put Nepal on the world Kayaking map. The Arun river was first explored by Mike Yager and Nepalese Guides in 1976 and an ABC Sportsman program filmed a kayak attempt on the Upper Arun in 1979. The Indian Navy descended the Kali Gandaki in the early 80's. In 1980 a British Expedition attempted a complete kayak descent of the Marshyangdi from its source. Bruce Mason led a descent of the Karnali River in 1981 (Knowles, 1994, p. 66). 
Subsequent to the introduction of rafting business, Nepalese teams attended the International Rafting Rallies in Switzerland in 1987, Siberia in 1988, USA in 1990, France in 1993, and Jambu- Kashmir in 2013 (Ranabhat \&Thapa, 2013, p.34). These events gave exposure to the participants in a new business, at the same time, its promotion and marketing in Europe and America. By the same time, rafting tourism was recognized as an important growing source of tourist revenue by His Majesty's Government. Meanwhile, the principal rafting operators formed a professional organization known as Nepal Association of Rafting Agents (NARA) in 1989. Kayaking has also been seen as a prime destination for the recreational whitewater kayaker in Nepal. Since the association was formed, rafting enterprise also got national recognition like other tourism organizations of Nepal.

\section{Nature of Rafting Trip}

Like trekking agencies, commercial operators offer many different styles of rafting trip to suit different peoples 'idea of a holiday. Knowles and Lama (1994) suggest the main choices are between: Participatory versus everything done for you; Lots of gear and comfort versus light and maneuverable; Large group versus "small is beautiful"; "A really cheap budget will dictate the style of the trip and give you no choice; the equipment will be poor and inadequate, food dreary, comforts few, guides inexperienced, etc. It will also probably be non-participatory and not reactive to clients need and wishes - when money is tight you cannot afford to be flexible! pay a little more, however, and there is a wide choice of different styles of trip" (Knowles, 1994, p.10).

There were only 14 rafting companies in 1988, but in course of development of rafting activities in Nepal, several companies were rapidly emerged. Now, there are 75 companies which might have invested approximately 1 billion Nepalese rupees (Ranabhat \& Thapa, 2013, p.81) for the SMEs (small and medium-sized enterprises). The definition of an SME varies significantly depending on geographic location. The EU has defined an SME as having less than 250 employees, less than $€ 50$ million in turnover and as being independent of larger enterprises (Buhalis \& Deimezi, 2004). Downie (2002) states that a similar definition is adopted in the USA, whereas in Australia and enterprise with less than 50 employees is considered a SME (Buhalis and Murphy, 2009, p. 288). SMEs are particularly important in developing and less industrialized countries. For example, micro businesses (those with fewer than 10 employees) dominate employment in countries such as Italy (47\%) and Poland (41\%). The majority of rafting operators, however, are small and medium - sized enterprises (SMEs) that own their own rafts and the Kayaks, operate on a localized set of rivers that they know well, hire whitewater guides trip by trip as required, and get most of their clients either through multi- activity outdoor tourism retailers such as World Expeditions ( Buckley, 2006, p.33).

So far as the rafting activities are concerned, the companies organize rafting trip in sixteen different rivers of Nepal. Out of which, the following rivers are categorized into three groups: (a) expedition (Sunkoshi, Bhotekoshi, Karnali, Tamore, Dudhkoshi); (b) Adventure (Bhotekoshi, Marshyangdi, Tamakoshi); and (c) Commercial (Trishuli, Seti, Kali Gandaki). Experienced tourists are involved in expedition and adventure tour. An 
inexperienced tourist will prefer to do rafting in the third category of rivers. In expedition trip it will take 7-10 days tour; 4- 5 days for adventure trip; and 1-3 for commercial trip. For these, a customer is charged minimum 30- 60 US \$ per day. Likewise, NPRs 2000 is charged to the Nepalese per day. While operating package tour, the companies facilitate transport, food, camping equipment, rafting equipment, river guide, helper and cook, including the safety measures in a full package basis. The authorities of NARA assumed that approximately 15,000-20,000 foreigners and 50,000 Nepalese undertook this activity in 2012.

Two thousand people have got employment directly and indirectly in this industry (Adhikari, 2013; Ranabhat \& Thapa (2013). In the beginning, the most of the guides, but not all, are found working as helpers to the guides in the river. After getting experiences, they go for training to get the license of river guide. The training given at NATHM will last for maximum for 10 days.

As one informant said those who used to work permanently as a guide, cook and helper were paid NPRs 6000 - 15000, 5000 - 8000 and 4000 - 6000, (excluding their trip facilities, i.e. lodging and fooding) as their salary on monthly basis respectively. Nowadays, most of the companies hire the rafting crew and pay them according to the nature of rivers on daily basis.

Since 1998, for the purpose of uplifting rafting business and promoting domestic tourism in Nepal, NARA is continuously organizing two events annually, i.e. Annual Rafting Festival and Faghu Jalayatra Mahotsav on last Saturday of May and in Falgun (Nepali month) on the occasion of Holi festival respectively. Likewise, since 2002, NARA is continuously organizing International Himalayan Whitewater Challenge Competition every year in Nepal. The purpose of organizing this competition is to expose Nepal as one of the important attractive whitewater rafting destinations in the world on one hand and promoting, marketing and developing adventure sport tourism on the other.

The above mentioned facts reveal that Nepal has been recognized as one of the most important sporting adventure tourist destinations in the world. This is proved by the above mentioned tourism statistics. Water sport tourism has also become the source of bread and butter for many people those who follow SMEs and people those who live in the river side who supply different kind of services to the rafters and the companies. This is justified to Van De Berg (n.d) by one of his informants who said, "I like to raft and I like to go rafting. In rafting I can have a good future. It is not bad work because in Nepal it is hard to get a job and rafting is good job. I like rafting, this is my life".

Of the 16 major rivers permitted by Government of Nepal for whitewater rafting and kayaking, the following rivers are the most popular adventure destination:

\begin{tabular}{|l|cc|c|c|c|c|c|}
\hline Rivers & Class & $\begin{array}{c}\text { Volumes } \\
\text { cumecs }\end{array}$ & $\mathbf{m} / \mathbf{k m}$ & $\begin{array}{c}\text { Total } \\
\text { days }\end{array}$ & $\begin{array}{c}\text { River } \\
\text { days }\end{array}$ & $\begin{array}{c}\text { Scenic } \\
\text { wild }\end{array}$ & $\begin{array}{c}\text { River } \\
\text { star }\end{array}$ \\
\hline Trishuli & $2 / 3+$ & 300 & 3 & $1-4$ & $1-4$ & $*$ & $* *$ \\
Upper Kali Gandaki & $4-$ & 120 & 5 & 3 & 3 & $* *$ & $* * *$ \\
Lower Kali Gandaki & 2 & 250 & 1.5 & 5 & 4 & $* *$ & $* *$ \\
\hline
\end{tabular}




\begin{tabular}{|l|cc|c|c|c|c|c|}
\hline Rivers & Class & $\begin{array}{c}\text { Volumes } \\
\text { cumecs }\end{array}$ & $\mathbf{m} / \mathbf{k m}$ & $\begin{array}{c}\text { Total } \\
\text { days }\end{array}$ & $\begin{array}{c}\text { River } \\
\text { days }\end{array}$ & $\begin{array}{c}\text { Scenic } \\
\text { wild }\end{array}$ & $\begin{array}{c}\text { River } \\
\text { star }\end{array}$ \\
\hline Marshyangdi & $4+$ & 80 & 10 & 5 & 4 & $* *$ & $* * *$ \\
Budhi Gandaki & 3 & 90 & 04 & 03 & 02 & $*$ & $*$ \\
Sun Koshi & $4-$ & 400 & 02 & 10 & 09 & $* *$ & $* * *$ \\
Upper Sunkoshi & 2 & 40 & 2 & 1 & 1 & $*$ & $* *$ \\
Bhote Koshi & $4+$ & 90 & 16 & 2 & 2 & $* *$ & $* * *$ \\
Karnali & 4 & 300 & 4 & 10 & 8 & $* * *$ & $* * *$ \\
Mahakali Seti/Karnali & 3 & 30 & 3 & 10 & 6 & $* * *$ & $*$ \\
Bheri & 3 & 130 & 4 & 9 & 6 & $* * *$ & $* *$ \\
Babai Nadi & $3+$ & 200 & 3 & 8 & 6 & $* * *$ & $* *$ \\
& 2 & 35 & 3 & 4 & 2 & $* * *$ & $*$ \\
\hline
\end{tabular}

Note:

1. Total days for a typical trip, to and from Kathmandu or Pokhara.

2. Scenic/Wild is our subjective rating for scenery and wildlife.

3. River star is our rating of the river as a kayaking trip- total experience.

*** Highly recommended. ** Recommended, *Specialist interest.

Source: Knowles and Alardice (1992; in Jarga, 2013)

\section{Guides and their roles}

After the establishment of NARA, it is continuously producing human resources, e.g. river guide and cook to meet the needs of the industry and to provide quality services to the clients. NARA provides training to the guides for 10 days in collaboration with Nepal Academy of Tourism and Hospitality Management (NATHM) (Ranabhat \& Thapa, 2013, p.80). The guides will be trained on First Aid, AR, CPR, SWRT and Rescue by the national and international expert. This training has produced quality workforce in the technical field of adventure water sport tourism. Up till now, NARA has already produced 1150 river guides. Out of them, 250 rafting guides are seen involving in this profession as mentioned by the authorities of NARA. Many other guides have gone abroad for working in the same field. The guides are the pillars of rafting industry. This is justified by a few scholars (Buckley, 2006; Lopez, 1980; Arnould \& Price, 1993) who have psychologically examined the role and responsibilities of the guides and their service aspects of adventure tours. As Parker and Avant (2000) saw the role of mountain climbing guides as 'educational' while Beedie (2003) described mountain guiding as 'choreography' and most recently Sharpe (2005) has applied the term as 'emotional labour' to river guiding.

A rafting guide requires a combination of soft and hard skill, i.e. knowledge about the 
river, rapids, level of water, holes and whirls, paddling and skill of negotiating with water. In the academic literature of tourism, recreation, and leisure studies, the main focus of risk management has been on physical safety during the adventure activity itself (Buckley, 2010, p.64). The skilled guides are a key component of physical risk management. This includes both the hard skills to carry out the relevant activities themselves and the soft skills to help clients do likewise.

Prior to start the adventurous trip in the river, the guide's job is to provide safety briefing on 'put in point' and, "if necessary, safety training and tests for all clients" (Buckley, 2010, p. 65). This is commonly combined with basic paddling instructions for those clients unfamiliar with the craft concerned. In whitewater paddle-raft trips, each raft commonly has a staff guide responsible for steering the boat, and during whitewater sections the staff may issue a near-continuous stream of commands to the clients, who are helping to propel and/ or balance the boat (Buckley, 2010, p. 79). According to the 'catastrophe theory' the release of adrenaline helps to improve sporting ability (Fox, 2000), although this is often a short-lived effect to permit 'flight or fight' activity bursts of a physical (gaining more strengthen) or mental (becoming more focused and less scared) nature (Swarbrooke et al., 2003, p. 77).

Apart from above mentioned, being a guide means having many different roles (see in detail Kunwar, 2009; 2011). A guide should also represent the country's things, like she must be knowledgeable and have physical fitness, be healthy and have good personality. One should know the clients' interests, whether they want to know about river rapids or existing environment of the river, riverine population and their activities in the riverside, culture, religion, ritual, environment and fauna. The guides, in this sense, are coined as 'culture brokers' in Europe and America. Nunez (1989) describes culture brokers in the following terms: "it is clear that in most situations a handful of people, no more economically or intellectually advantaged than their peers, appear to emerge as culture brokers. They learn the necessary second or third language; they change occupations from subsistence or salaried to entrepreneurial; they migrate to potential or developing resort areas, etc.; and if they are successful, they are emulated by the previously less daring" (p.269). Now they have got prestigious tourism community leadership

In multi-day trips, where there is more information to convey, it is commonly reserved for a briefing at the first day's campsite, either on arrival or after the clients have eaten. Such briefings typically include information on: toilet practices, and cleaning, washing, litter control, and other environmental management issues. For example, once in the rafting trip of the western Nepal, according to Buckley (2010), camping sites were environmentally, ecologically and aesthetically polluted from the clients, because of poor communication made by the guide. To which Buckley (2010) focuses on proper communication which should be made by the guide during the trip. From sustainable environmental perspectives, the guides are required to have the managerial skills of the following areas: 
Major Subjects of Routine Communications

\begin{tabular}{|l|l|}
\hline Subject & Examples \\
\hline Relevant to tour & \\
Safety & Throw rope, avoid anger \\
Logistics & Life boat, carry gear \\
Logistics, planned & Campsites, stops, day's journey, cooking \\
Equipment & Expected weather, clothing needs, tents, tarps \\
Hygiene & Washing, fires, human waste \\
Hygiene & Do not drop litter, butts \\
Hygiene & Wash hands, filter water, toilet practice \\
Observation & Wildlife, rapid \\
Relationships, on-tour & Existing or new \\
\hline
\end{tabular}

Source: Buckley (2006, pp.76-77)

Each tour consists of two different subgroups, the guides and the clients, respectively, who assembly only for the tour and then disperse again. Some of the clients are experienced, that is, they take part in numerous tours of the same general type and thus have an intermittent 'river life' distinct from their 'home life' but with a degree of continuity over time. Other clients are experienced: they take one tour as an adventure holiday, and it forms an isolated experience in their life with no other basis for direct comparison. Likewise, some of the guides run the same tours repeatedly all season or indeed year after year: for that period at least, tour guiding provides their living, the tour experience is a central component of their life, and if other guides work the same tour, they form a wellestablished social workgroup. Other guides work only intermittently or occasionally, or work on different tours each time and each season, making their living principally from other professions (Buckley, 2010, p.73-75). It is the guide who will not only save the life of the clients, but also he will create fun and thrilling from such adventurous tour in the river.

For different types of tours, there may be more guides than clients or many more clients than guides. For many types of commercial adventure tours, client-to-guide ratios seem to range from about 4:1 to about 12:1 (Buckley, 2007a), but these ratios do not necessarily apply across all types of activities.

Buckley (2006) while describing about the importance of communications in the rafting operation and management, he has categorized four main types of communications, which are considered as quintessential for solving the problems and making successful trip. According to him, "First is the overall conversational context where the same patterns are repeated consistently. Second are routine but critical operational communications, notably those related to risk and safety, health and hygiene, and client satisfaction Third are emergency communications, occurring when at least one participant was at potential 
risk of immediate injury or death; and fourth are communications which though not emergencies, nonetheless involved strong emotional overtones for the participants for a variety of reasons" (p. 76).

\section{Women River Guide}

Twenty five years after the introduction of rafting tourism enterprises, the Nepalese women gradually entered into this field. It is Mina Gurung who served as the first river guide in Nepal. Later on, approximately, according to the informants, there were altogether thirty women who showed their interest in this sector for working as river guide and kayaker. Some of them have got basic training in the river and eighteen to twenty women got license of river guide from NATHM. Among them, a considerable number of the female guides are involved in this profession. Even some married women are still continuing this profession with a great enthusiasm. Two female guides visited abroad for contesting international rafting competition. It is noticed that the two rafting guides are working in the same profession in the foreign countries. Remaining other six to nine guides are providing services in Kathmandu and Pokhara. All of them are equally competent in handling, paddling, kayaking and guiding in the river. The six courageous, outdoor seekers and strenuous guides have recently established an agency named Himalayan Adventure Nepali Girls which seems to be parallel to 'three sisters' (emphasis added) trekking of Pokhara (see in detail Daddi, 2001). They seem to be quiet enthusiastic for guiding, working and contributing to this field.

Women working as guides in the field of rafting tourism are new phenomenon in Nepal. It has opened a door for women's employment changing their new images and survival. They feel proud of working as rafting guides and kayakers. Most of them think that tourism has given another dimension of work to be engaged in income generating roles. At the same time, they are able to overcome the obstacles by meeting their societal traditional expectations, although the women have not been able to capture in this business in comparison to men. The way they have entered into this profession symbolizes that they have been gradually breaking into male's dominating profession. For women guides, for example, paddling and steering the boat, crossing over the rapids, commanding the clients and balancing the boat, is an empowering experiences "pumping of adrenaline rush" (Swarbrooke, 2003, p. 77). They feel stronger and more confident, ready to face their own society with the knowledge which they have "done it", that they have overcome the test to which Ortner (1999) coined the term "gender radical" (p.217) in the study of Sherpa women and their involvement in trekking business. In order to justify it, she has further used the term "games of liberation" (p.23; in Daddi, 2001 ) as breaking gender rules. The above mentioned concepts can be linked with the bravery of women river guides of Nepal. In the case of tourists, they feel that (they) have achieved this tour, and in general many of the tourists seem to be indulged in an atmosphere of excitement and thrilling, in contrast to the conventions of everyday life, forming a "structure societus to unstructured communitas" (Turner ,1969; Turner and Turner 1973; see in detail Kunwar, 2012, pp. 110-112). This concept has become a new agenda for further research in the field of women river guiding. 


\section{Conclusion}

The concept of sport tourism has become more prominent in the last few years as both an academic field of study and an increasingly popular tourism product. However, the links and relationship between sport and tourism have largely been overlooked. More importantly, the genre of 'sport tourism' is a recent research development. Those who studied sport tourism as an academic subject, they have suggested that the development of sport and tourism is crucial for social and economic benefits. Sport tourism has been recognized one of the most entertaining and exciting tourism in the world. There are two types of sport tourism: active sport tourism and passive sport tourism. Likewise, the sport tourists are also classified into two: the 'general dabbler' and 'specialist' to describe different levels of tourist engagement in participant and spectator sports. Sport-as-play normally associated with active tourist behavior (taking part in sport), while sport-ascompetition is usually associated with passive tourist behavior (witnessing sport).

This study focuses mainly on non-competitive and informal types of sport tourism to which the scholars prefer to use the term as sporting adventure travel as noted earlier. Sport tourism is closely linked with nostalgia. Environment, landscape, space, place, season, culture, identity and image of the people and host country are the essential elements or markers of sport tourism. However, crime, hooliganism, insecurity, negative reactions of the communities cannot be ignored in the study of sport tourism. The concepts, theories, models, approaches, perspectives and paradigms are the key methodological tools for understanding sport tourism and adventure sport in better way. Nepal is one of the most popular adventure tourism destinations in the world where many extra ordinary tourists undertake both soft and hard activities in different places of Nepal. Hence, this study suggests that interdisciplinary research is required to advance the knowledge of sport tourism for students, researchers, policy makers and entrepreneurs.

In the case of Nepal, this preliminary study suggests to the students and researchers to carry out research on conflict between the rafting entrepreneurs and hydroelectric producers, water and heritage, the status of river guide and crucial encounter, gender study, impact of rafting tourism on the riverine population of the 'put-in' and 'take-out' points. In order to promote aqua tourism in Nepal, research in this field is quintessential.

The overall potential research outcomes from the synergic approach includes tourism studies, business studies, social sciences, sport management and leisure studies are as follows:

- Better understanding of the interrelationship between the segments and various components of sport tourism,

- Better understanding of the economic, social, environmental and personal impacts generated from sport tourism,

- Better understanding of the management issues associated with the planning, development and management of sport tourism (Ritchie and Adair, 2006, p.296).

As they hoped, "this catholic approach to sport tourism has provided the reader with a better understanding of the breadth and depth of the field" (p.295). 


\section{References}

Ap, J. (1992). Residents' perceptions on tourism impacts. Annals of Tourism Research, 19 (4), 665-690.

Adair, D. (2006). Where the games never cease: The Olympic museum in Lausanne, Switzerland. In Ritchie, B. W. and Adair, D. (Eds.), Sport Tourism Interrelationships, Impact and Issues (pp. 46-76). New Delhi: Viva Books.

Adhikari, K. (2013). Nepalma Jalyatrako Sambhavana ra Chunauti (in Nepali). NARA Silver Jubilee Souvenir - 2013, Kathmandu: NARA.

Arnould, E. \& Price, I. (1993). River magic: Extraordinary experience and the extended service encounter. Journal of Consumer Research, (20), 24-45.

Blaine, M. (2001). Whitewater: The thrill and skill of running the world's great Rivers. New York: Black Dog and Liventhal Publishers.

Buckley, R. (2006). Adventure Tourism, New York: CABI Publishing.

........., (2010). Adventure Tourism Management, Amsterdam: Elsevier.

Buhalis, D. \& Costa, C. (2006). Tourism management dynamics: trends, management and tools (Eds.), Amsterdam: Elsevier, Butterworth Heinemann.

Buhalis, D. and Murphy, H. (2009). Information Communication Technologies (ICTs), Entrepreneurship and SMTEs. In Ateljevic, J. \& Page, S. J. (Eds.) Tourism and Entrepreneurship International Perspectives, (pp. 287-300) Amsterdam: Elsevier.

Bale, J. (1989). Sports Geography. London: E and F.N. Spon.

Barker, M. (2006). Crime and sport events tourism: The 1999-2000 America's Coup. In Ritchie, B. W. and Adair, D. (Eds.), Sport Tourism Interrelationships, Impact and Issues (pp. 174-191). New Delhi: Viva Books,

Beke, B. and Elands, B. (1995). Managing Deviant Tourist Behaviour. In Ashworth,G. J. an A.G. J. Dietvorst (Eds.), Tourism and Spatial Transformations (pp. 285-301). Wallingford: CAB International.

Beresford, S. (1999). The sport-tourism link in the Yorkshire region, In Scarrot, M. (Eds.), Exploring Sports Tourism: Proceedings of a SPRIG Seminar Held at the University of Sheffield on 15 April 1999 (pp. 29-37). Sheffield: Sheffield Hallam University.

Bourdeau, P., Jean, C. \& Pascal, M. (2006). Adventure sports and tourism in the French mountains: Dynamics of change and challenges for sustainable development. In: Ritchie, B.W. and Adair, D.(Eds.), Sport Tourism Interrelationships, Impact and Issues (pp. 101-116). New Delhi: Viva Books.

Coakley, J. (2001). Sport in society: issues and controversies. Boston: McGraw- Hill.

Cockerell, N. (1988). Skiing in Europe - potentials and problems. .Travel and Tourism Analysts, (5), 66-81.

Daddi, Stephanie (2001). Women Guiding Trekkers: In-Roads to a Men 's World, An Unpublished Thesis Submitted to the Cornell Nepal Study Program. 
Deane, J. \& Callanan, M. (2006). Sport Tourism in the UK: Policy and Practice. In Ritchie, B.W. and Adair, D.(Eds.), Sport Tourism Interrelationships, Impact and Issues (pp. 253-281). New Delhi: Viva Books.

Dhakal, D. P. (2013). Mountain tourism benefitting Nepal's economy. Nepal Parbat Special Issue- Everest Diamond Jubilee Celebration, May 27-29, pp. 66-68.

Eagly, A. H. \& Chaiken, S. (1993). The Psychology of Attitudes. Orlando: Harcourt Brace Jouanovich.

Emerson, R. (1972). Exchange theory, Part I: A Psychological Basis for Social Exchange. in Berger, J., Zelditch, M. and Anderson, B. (Eds.), Sociological Theories in Progress (pp. 38-87). New York: Houghton-Mifflin,

Faulkner, B. (2001). Towards and framework for tourism disaster management. Tourism Management, 22(2), 135-147.

Fredline, L. (2006). Host community reactions to motorsport events: The perception of impact on quality of life. in Ritchie, B. W. and Adair, D. (Eds.), Sport Tourism Interrelationships, Impact and Issues ( pp. 155-173). New Delhi: Viva Books.

Gammon, S. \& Robinson, T. (1997). Sport and tourism a conceptual framework. Journal of Sport Tourism, 4 (3), 8-24.

Gibson, H. (1998). Sport tourism: A critical analysis of research. Sport Management Review, 1 (1), 45-76.

Glyptis, S.(1991).Sport and Tourism. In C. Cooper (Eds.) Progress in Tourism (pp. 166183). London: Belhaven Press.

Government of Nepal, Ministry of Tourism and Civil Aviation ( 2009). Tourism Vision 2020, Kathmandu: Ministry of Tourism and Civil Aviation.

Hall, C. M. (2006). Sport tourism and urban regeneration. In Ritchie, B. W. and Adair, D. (Eds.), Sport Tourism Interrelationships, Impact and Issues (pp. 192-205). New Delhi: Viva Books.

Herda, P. S. (1993). Tourism and alcohol use in Wanaka, Queenstown and Arrowtown. Department of Anthropology, University of Auckland.

Hinch, T. \& Higham, J. (2003). Sport Tourism Development. New Delhi: Viva Books.

HMG, Ministry of Tourism \& Civil Aviation (1994 ). Some Provisions Relating to Mountain Tourism in Nepal, Kathmandu: Ministry of Tourism \& Civil Aviation.

Holloway, C. (1994).The Business of Tourism. London: Pitman.

Jafari, J. (2000). Encyclopedia of tourism. London: Routledge.

Jarga, T. B. (2013). Facts and Figures about Nepal. NARA Silver Jubilee Souvenir-2013. Kathmandu: NARA.

Knowles, P. (1994). Rafting Nepal: A consumers' guide. UK: Rivers Publishing.

Knowles, P. \& Allardice, D. (1992). White Water Nepal. Birmingham: Albana and Rivers Publishing. 
Kunwar, R. R. (2012). Tourists and tourism: Science and industry interface. Kathmandu: Ganga Sen (Kunwar).

..........., (2009). Community Tourism, Interpretation, Themes and Education. The Gaze Journal of Tourism and Hospitality, (1) 1, 1-16.

............, (2011). Tourism, Tourist Guide and Interpretation. Journal of Tourism and Hospitality Education, (1) 1-26.

Kelly, I. (1993). Tourist destination crime rates: An examination of Cairns and the Gold Coast Australia. The Journal of Tourism Studies, 4 (2), 2-11.

Kruk, E. (2011). Tourism and Sustainable Mountain Development in the Hindu KushHimalayas. In Kruk, E., Kreutzmann, H. and Richter, J (Eds.), Integrated Tourism Concepts to Contribute to Sustainable Mountain Development in Nepal, giz: (pp. 1529). ICIMOD and BMZ: Kathmandu.

Kundsen, D. C., Metro-Roland, M. M., Soper, A. K. and Greer, C. E. (2008). Landscape, Tourism, and Meaning: An Introduction. In Kundsen, D. C., Metro-Roland, M. M., Soper, A. K. and Greer, C. E. (Eds.), Landscape, Tourism, and Meaning. Hampshire: ASHGATE.

Kurtzman, J. (2000). Sport and tourism relationship: A unique reality. In Ritchie, B.W. and Adair, D. (Eds.), Sports generated tourism: Exploring the nexus (pp.5-22). Proceeding of the first Australian Sports Tourism Symposium, Canberra: University of Canberra.

Kurtzman, J. and Zauhar, J. (The Late) (2006). The Future of Sport Tourism: The Perspectives of Sports Tourism International Council. In Ritchie, B. W. and Adair, D. (Eds.), Sport Tourism Interrelationships, Impact and Issues (pp. 281-292). New Delhi: Viva Books.

Lee, Y. F. \& Harold, J. R. (1999). Critical issues for area impact analysis in business crisis management: Analytical capability. Disaster Prevention and Management, 8 (3), 184-189.

Lindberg, K. \& Johnson, R. (1997). Modeling resident attitudes toward tourism. Annals of Tourism Research, 24 (2), 402-424.

MacAloon, J. (1984). This Great Symbol: Pierre de Caubertin and the origins of the modern Olympic games, Chicago: IL: University of Chicago Press.

Mark, B. (2001). White water the thrill and skill of running the world's great river. New York: Black Dog \& Leventhal Publishers.

McLennan, M. (2000). The untold history. Ski Canada, 29(3), 74-81.

Melkort, M. and Katleen, V.(2010). A Comparison of Quantitative and Qualitative Approaches: Complementarities and Trade- offs. In Richards, G. and Munsters, W. (Eds.), Cultural Tourism Research Methods (pp. 33-40). New York: CABI Publishing.

Miller, G. A. \& Brent W. R. (2006). Sport tourism in crisis: exploring the impact of the foot-and-mouth crisis in the UK," in Brent W. Ritchie and Daryl Adair (Eds.), Sport Tourism (pp. 206-225). New Delhi: Viva Books. 
Miller, G., Hudson, S. and Turner, R. (2005). Applying the Mystery Shopping Technique: the Case of Lunn Poly. In Ritchie, B. W., Burns, P. and Palmer, C. (Eds.), Tourism Research Methods (pp. 119-130). Wallingford: CABI Publishing.

MoCTCA. (2013). Nepal Tourism Statistics 2012. Kathmandu: Government of Nepal, Ministry of Culture, Tourism and Civil Aviation.

Moscovici, S. (1981). On social representations. in Forgas, J. P. (Eds.), Social cognition: Perspectives of everyday understanding (pp.181-209). London: Academic Press.

Nyaupane, G. P. \& Poudel, S . (2011) Linkages among Biodiversity, Livelihood, and Tourism. Annals of Tourism Research, 38 (4), 1344-1366.

Ortner, S. (1999).Life and Death on Mt.Everest,Princeton,NJ: Princeton University Press.

Pearce, P. L., Moscardo, G. \& Ross, G. F. (1996). Tourism Community Relationships. Oxford: Pergamon.

Pereiro, X. (2010). Ethnographic Research on Cultural Tourism: an Anthropological View. In Richards, G. and Munsters, W. (Eds.), Cultural Tourism Research Methods. (pp. 173-187). Wallingford: U.K. CABI.

Pitts, B. (1999). Sport tourism and niche markets: Identification and analysis of the growing lesbian and gay sports tourism industry. Journal of Vacation Marketing, 5 (1), 31-50.

Ranabhat, K. \& Thapa, N. (2013). Nepalko Sahashik Jalayatra Paryatan (in Nepali). NARA Silver Jubilee Souvenir- 2013, Kathmandu: NARA.

Ritchie, B. W. \& Daryl, A. (2006). Sport tourism: An introduction and Overview. In Brent W. Ritchie and Daryl Adair (Eds.), Sport Tourism Interrelationships, Impacts and Issues (pp. 1-29). New Delhi: Viva Books.

Ritchie, B. W., Burns, P. and Palmer, C. (2005). Introduction: Reflections on the Practice of Research. In Ritchie, B. W., Burns, P. and Palmer, C. (Eds.), Tourism Research Methods (pp. 1-8). Wallingford: CABI Publishing.

Redmond, G. (1991). Changing styles of sports tourism: Industry/consumer interactions in Canada, the USA and Europe. In Sinclair, T. and Stabler, M.J. (Eds.), The Tourism Industry - An International Perspective. Oxon: CAB International.

Repko, A. F. (2012). Interdisciplinary Research Process and Theory. London: SAGE.

Ritchie, B. W. (2006). Exploring small-scale sport event tourism: The case of rugby union and the supper 12 competition. In Ritchie, B.W. and Adair, D. (Eds.), Sport Tourism Interrelationships, Impact and Issues (pp. 135-154.). New Delhi: Viva Books.

Robins, D. (1990). Sport as prevention: The role of sport in crime prevention programs aimed at young people. Occasional Paper (12), Centre for Criminological Research. Oxford: University of Oxford.

Sharpe, R. (2005). Going above the beyond the emotional labour of adventure guides. Journal of Leisure Research, (37), 29-50.

Swarbrooke, J., Colin, B., Suzanne, L. \& Gill, P. (2003). Adventure Tourism: The New Frontier. Butterworth/ Heinemann. 
Standeven, J. \& De Knop, P. (1999). Sport Tourism. Champaign, IL: Human Kinetics.

Swart, K. (2000). An assessment of sport tourism curriculum offerings at academic institutions. Journal of Sport Tourism, 6(1), 11-18.

Tarlow, P. E. (2009). Tourism Safety and Security. In Jamal, T. and Robinson, M. (Eds.), SAGE Handbook of Tourism Studies (pp. 464-488). London: SAGE.

Thompson, A. (1999). Security. In R. Cashman and A Hughes (Eds.), Staging the Olympics: The events and its impact (pp. 106-120). Sydney: University of New South Wales Press.

Turner, V. (1969). The Ritual Process: Structure and Anti-Structure. New York: Aldine publishing.

Turner, V. and Turner, E. (1973). The Center Out There: Pilgrim's Goal. History if Religions.

Van De Berg, William (n.d.). Tourism globalization and a multi- cited approach to field work in Nepal. The Journal of Ecological Anthropology, (in Press).

Weed, M. \& Bull, C. (1999). The Search for a sport-tourism policy network. In Collins, M. F. and Cooper, I. (Eds.), Leisure Management Issues and Applications. Oxon: CAB International.

Williams, P. (2010) Educational Tourism: Understanding the Concept, Recognizing the Value. Retrieved from http://www.insight.org.uk/articleitem.aspx?title=Educational \%20Tourism:\%20Understanding\%20the\%20Concept, \%20Recognizing\%20the $\% 20$ Value

Xie, P.F. (2006). The Development of Cultural Iconography in Festival Tourism. In Burns, P. M. and Novelli, M. (Eds.), Tourism and Social Identities: Global Frameworks and Local Realities (pp. 125-136). Amsterdam: Elsevier.

Yandall, P. (2001). Camera footage shows your bag can be gone in a blink. The New Zealand Herald, 2nd June, 2001.

Young-Shim, D. (2004). Poverty reduction through the dynamic synergy of tourism and sports. Paper presented on $27^{\text {th }}$ September 2004 at the International Conference on Sports and Tourism: Two living forces for mutual understanding organized by Culture and the Development of Societies. Kuala Lumpur.

\section{Acknowledgements}

I would like to express my sincere thanks to Rita Dhungel, a Ph.D. research scholar of University of Calgary, Canada, for making valuable comments and suggestions to this paper. Similarly, I would also like to thank to Bibek Raj Kunwar, a student of Travel and Tourism, NATHM, T.U. for typing this manuscript. Finally, I would like to thank to my wife, Ganga Sen (Kunwar) who was instrumental in making this paper a reality. 